\title{
Deteksi Sepsis pada Bayi Menggunakan Metode Dempster-Shafer
}

\author{
I Wayan Ryon Waryanta ${ }^{1}$, I Ketut Gede Darma Putra ${ }^{2}$, I Ketut Adi Purnawan ${ }^{3}$ \\ Jurusan Teknologi Informasi Universitas Udayana, Bukit Jimbaran, Bali, Indonesia \\ 1ryonwaryanta@gmail.com \\ 2ikgdarmaputra@gmail.com \\ 3dosenadi@yahoo.com
}

\begin{abstract}
Abstrak
Sepsis menjadi masalah kesehatan yang diperhatikan pada bayi di negara berkembang maupun negara industri. Hal tersebut dikarenakan sepsis memiliki angka kematian yang cukup tinggi pada bayi. Kurangnya pengetahuan orang tua terhadap penyakit sepsis menyebabkan penanganan yang terlambat. Penelitian ini berusaha menunjukkan bagaimana Metode Dempster-Shafer dapat dimanfaatkan untuk mendeteksi Penyakit Sepsis pada Bayi. Metode Dempster-Shafer mengkombinasikan Nilai Kepercayaan gejala satu demi satu. Metode ini merupakan model ketidakpastian dengan range probabilities. Penelitian menggunakan 6 gejala pada 5 macam kondisi Nilai Kepercayaan yang berbeda dari setiap gejala. Uji coba penelitian diaplikasikan menggunakan Bahasa Pemrograman PHP dan HTML. Hasil Dempster-Shafer untuk Sepsis pada Bayi yaitu Kondisi 1 adalah 0.66977, Kondisi 2 adalah 0.60435, Kondisi 3 adalah 0.69249, Kondisi 4 adalah 0.66132, dan Kondisi 5 adalah 0.76756.
\end{abstract}

Kata Kunci: Sepsis, Metode Dempster-Shafer.

\begin{abstract}
Sepsis be considered health problems in infants in developing countries and industrialized countries. That is because sepsis has a mortality rate that is enough high on the infants. Lack of knowledge of parents to the sepsis causing treatment too late. This study attempted to show how the Dempster-Shafer method can be used to detect Sepsis disease in Infants. Dempster-Shafer method combines Trust Value of symptoms one by one. This method is a model uncertainty with a range of probabilities. The study used six symptoms on 5 kinds of different conditions of Trust Value from any symptoms. The trials applied using the programming language PHP and HTML. The results of Dempster-Shafer for Sepsis in Infants that Condition 1 is 0.66977, Condition 2 is 0.60435 , Condition 3 is 0.69249, Condition 4 is 0.66132 , and the Condition 5 is 0.76756 .
\end{abstract}

Keywords: Sepsis, Dempster-Shafer Method

\section{Pendahuluan}

Bayi sangat rentan terhadap kuman penyakit sehingga orang tua perlu memperoleh informasi mengenai penyakit yang diderita bayi. Infomasi ini sangat penting karena orang tua akan mampu melakukan tindakan awal yang tepat sehingga penyakit tidak mencapai tahap kronis dan lebih mudah disembuhkan. Sepsis merupakan salah satu penyakit yang dapat diderita bayi. Sepsis menjadi masalah kesehatan yang diperhatikan pada bayi di negara berkembang maupun negara industri. Hal tersebut dikarenakan sepsis memiliki angka kematian yang cukup tinggi pada bayi [1].

Dempster-Shafer adalah suatu teori matematika untuk pembuktian berdasarkan belief functions and plausible reasoning (fungsi kepercayaan dan pemikiran yang masuk akal). Metode Dempster-Shafer dikembangkan oleh Arthur P. Dempster dan Glenn Shafer [2]. Metode ini mengkombinasikan potongan informasi yang terpisah (bukti) untuk mengkalkulasi kemungkinan dari suatu peristiwa. 
Metode Dempster-Shafer dimanfaatkan untuk mendeteksi Penyakit Sepsis pada Bayi dengan menelusuri gejala penyakit satu demi satu. Penelitian Deteksi Sepsis pada Bayi Menggunakan Metode Dempster-Shafer diuji coba menggunakan Bahasa Pemrograman PHP dan HTML. Uji coba dilakukan pada 5 macam kondisi Nilai Kepercayaan yang berbeda.

\section{Metodologi Penelitian}

Metodologi penelitian membahas mengenai langkah akuisisi pengetahuan yang digunakan di dalam penelitian Deteksi Sepsis pada Bayi Menggunakan Metode Dempster-Shafer dan membahas mengenai metode pengumpulan data.

\subsection{Alur Penelitian}

Alur penelitian dari Deteksi Sepsis pada Bayi Menggunakan Metode Dempster-Shafer yang dilakukan dalam penelitian ini adalah seperti Gambar 1.

1. Pendefinisian masalah dari penelitian yang dilakukan.

2. Pengumpulan data melalui studi literatur dan wawancara.

3. Mempelajari Bahasa Pemrograman PHP dan HTML yang digunakan dalam uji coba penelitian.

4. Pengujian terhadap perhitungan yang telah dibuat kemudian melakukan analisis hasil pengujian.

5. kesimpulan.

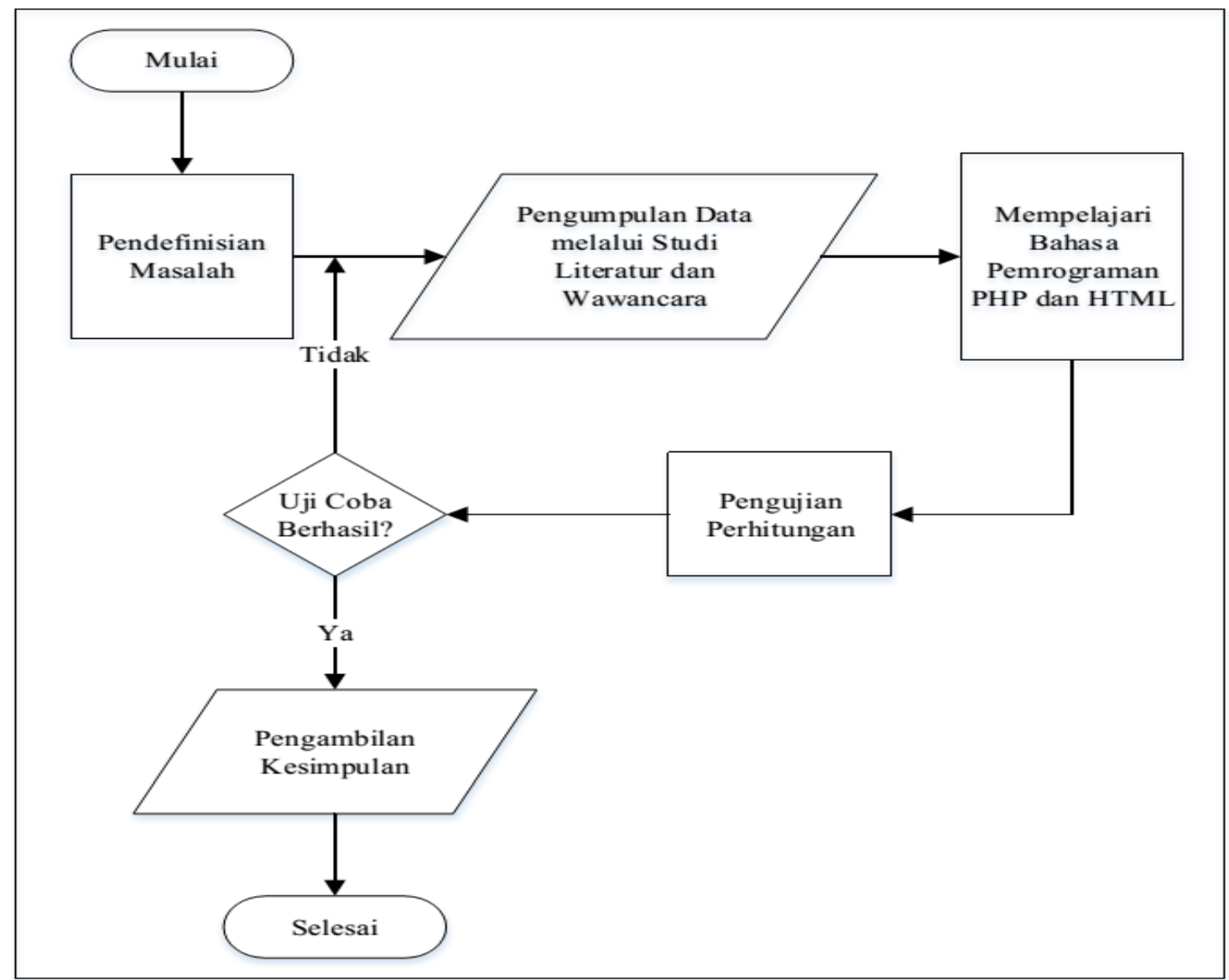

Gambar 1. Flowchart Alur Penelitian

\subsection{Metode Pengumpulan Data}

Metode Wawancara adalah suatu cara mengumpulkan data dengan cara mengajukan pertanyaan langsung kepada seorang informan atau autoritas atau seorang ahli yang berwenang dalam suatu masalah. Metode Studi Literatur digunakan dengan cara mengumpulkan data dari 
buku-buku referensi ataupun e-book, serta data berupa laporan yang relevan dengan objek permasalahan.

\subsection{Data Penelitian}

Data penelitian meliputi data gejala dan penyakit yang terkait dengan gejala. Setiap gejala diberikan 5 kondisi untuk nilai kepercayaannya yang dapat dilihat pada Tabel 1.

Tabel 1. Nilai Kepercayaan Setiap Gejala

\begin{tabular}{|c|c|c|c|c|c|c|c|}
\hline No. & Gejala & Penyakit & Kondisi 1 & Kondisi 2 & Kondisi 3 & Kondisi 4 & Kondisi 5 \\
\hline 1. & Panas & $\begin{array}{c}\text { Sepsis } \\
\text { pada Bayi } \\
\text { Meningitis } \\
\text { Kejang } \\
\text { Demam } \\
\text { Bronkitis }\end{array}$ & 0.7 & 0.6 & 0.5 & 0.55 & 0.45 \\
\hline 2. & $\begin{array}{l}\text { Tangis } \\
\text { Merintih }\end{array}$ & $\begin{array}{l}\text { Sepsis } \\
\text { pada Bayi } \\
\text { Bronkitis }\end{array}$ & 0.6 & 0.5 & 0.55 & 0.45 & 0.4 \\
\hline 3. & $\begin{array}{l}\text { Tidak } \\
\text { Mau } \\
\text { Minum }\end{array}$ & $\begin{array}{c}\text { Sepsis pada } \\
\text { Bayi }\end{array}$ & 0.5 & 0.55 & 0.45 & 0.4 & 0.7 \\
\hline 4. & Sesak & $\begin{array}{c}\text { Sepsis } \\
\text { pada Bayi } \\
\text { Bronkitis } \\
\text { Asma } \\
\text { Sepsis }\end{array}$ & 0.55 & 0.45 & 0.4 & 0.7 & 0.6 \\
\hline 5. & Kejang & $\begin{array}{l}\text { Meningitis } \\
\text { Kejang } \\
\text { Demam }\end{array}$ & 0.45 & 0.4 & 0.7 & 0.6 & 0.5 \\
\hline 6. & Batuk & Asma & 0.4 & 0.7 & 0.6 & 0.5 & 0.55 \\
\hline
\end{tabular}

Nilai Kepercayaan pada Tabel 1 digunakan dalam perhitungan Metode Dempster-Shafer untuk Deteksi Sepsis pada Bayi.

\section{Kajian Pustaka}

Kajian pustaka berisikan dasar teori yang menunjang dalam pelaksanaan Deteksi Sepsis pada Bayi Menggunakan Metode Dempster-Shafer yang ditemukan dalam beberapa literatur.

\subsection{Sepsis}

Sepsis adalah suatu sindroma klinik yang terjadi sebagai manifestasi proses inflamasi imunologi karena adanya respon tubuh yang berlebihan terhadap rangsangan produk mikroorganisme [3]. Gejala dari penyakit sepsis pada bayi yaitu panas, tangis merintih, tidak mau minum, sesak, dan kejang. Kematian karena sepsis masih cukup tinggi, meskipun kemajuan di bidang antimikroba telah berkembang dengan ditemukannya obat-obat baru.

Sepsis disebabkan oleh kehadiran bakteri (bakteremia) dan organisme penginfeksi lainnya atau racun dalam darah (septikemia). Sepsis perlu perawatan mendesak dan komprehensif. Diagnosis cepat sangat penting, karena sepertiga dari penderita sepsis meninggal dunia. Penderita sepsis biasanya dirawat di unit perawatan intensif rumah sakit (ICU) [4]. 


\section{2. $\quad$ Teori Dempster-Shafer}

Metode Dempster-Shafer pertama kali diperkenalkan oleh Dempster, yang melakukan percobaan model ketidakpastian dengan range probabilities dari pada sebagai probabilitas tunggal [5]. Tahun 1976, Shafer menerbitkan teori Dempster dalam sebuah buku berjudul Mathematical Theory of Evident [6]. Secara umum Teori Dempster-Shafer ditulis dalam suatu interval:

$$
\text { [Belief, Plausibility] }
$$

a. Belief

Belief (Bel) adalah ukuran kekuatan evidence (gejala) dalam mendukung suatu himpunan bagian. Jika bernilai 0 maka mengindikasikan bahwa tidak ada evidence, dan jika bernilai 1 menunjukan adanya kepastian.

b. Plausibility

Plausibility juga bernilai 0 sampai 1 , jika kita yakin terhadap $-s$, maka dapat dikatakan bahwa $B e l(-s)=1$, dan $P I(-s)=0$. Plausibility mengurangi tingkat kepercayaan dari evidence. Teori Dempster-Shafer kita mengenal adanya frame of discernment yang dinotasikan dengan $\theta$ dan mass function yang dinotasikan dengan $m$. Frame ini merupakan semesta pembicaraan dari sekumpulan hipotesis sehingga disebut dengan environtment. Plausibility (PI) dinotasikan sebagai:

$$
[\operatorname{Pl}(s)=1-\operatorname{Bel}(-s)]
$$

\section{c. Mass Function}

Mass function $(m)$ dalam Teori Dempster-Shafer adalah tingkat kepercayaan dari suatu evidence measure sehingga dinotasikan dengan $(m)$. Untuk mengatasi sejumlah evidence pada Teori Dempster-Shafer menggunakan aturan yang lebih dikenal dengan Dempster's Rule

of Combination.

Dimana,

$$
m_{3}(Z)=\frac{\sum x \cap y=z}{m_{1}(X) \cdot m_{2}(Y)}
$$

$$
K=\sum_{x \cap y=\varnothing} m_{1}(X) \cdot m_{2}(Y)
$$

Keterangan:

$m 1(X)$ adalah mass function dari evidence $X$.

$m 2(Y)$ adalah mass function dari evidence $Y . m 3(Z)$ adalah mass function dari evidence $Z . \mathrm{K}$ adalah jumlah conflict evidence.

\section{Hasil dan Pembahasan}

Hasil dan pembahasan membahas mengenai pengujian penelitian dan analisis hasil yang didapat setelah melakukan pengujian terhadap penelitian Deteksi Sepsis pada Bayi dan hasil dari penelitian.

\subsection{Perhitungan Dempster-Shafer}

Perhitungan Dempster-Shafer untuk Deteksi Sepsis pada Bayi mengikuti gejala yang telah disampaikan pada Tabel 1.

a. Gejala 1: Panas

Panas merupakan gejala dari Sepsis pada Bayi $\{S\}$, Meningitis $\{M\}$, Kejang Demam $\{K D\}$, dan Bronkitis $\{\mathrm{B}\}$ dengan Nilai Kepercayaan adalah 0.7.

$\mathrm{m}_{1}\{\mathrm{~S}, \mathrm{M}, \mathrm{KD}, \mathrm{B}\}=0.7 \mathrm{~m}_{1}\{\Theta\}=0.3$

b. Gejala 2: Tangis Merintih

Tangis merintih merupakan gejala dari Sepsis pada Bayi $\{S\}$ dan Bronkitis $\{B\}$ dengan Nilai Kepercayaan adalah $0.6 . \mathrm{m}_{2}\{\mathrm{~S}, \mathrm{~B}\}=0.6$

$\mathrm{m}_{2}\{\Theta\}=0.4$ 
Tabel 2. Kombinasi 2 Gejala

\begin{tabular}{lll}
\hline & $\mathrm{m}_{2}\{\mathrm{~S}, \mathrm{~B}\} 0.6$ & $\mathrm{~m}_{2}\{\Theta\} 0.4$ \\
\hline $\mathrm{m}_{1}\{\mathrm{~S}, \mathrm{M}, \mathrm{KD}, \mathrm{B}\} 0.7$ & $\{\mathrm{~S}, \mathrm{~B}\} 0.42$ & $\{\mathrm{~S}, \mathrm{M}, \mathrm{KD}, \mathrm{B}\} 0.28$ \\
$\mathrm{~m}_{1}\{\Theta\} 0.3$ & $\{\mathrm{~S}, \mathrm{~B}\} 0.18$ & $\{\Theta\} 0.12$ \\
\hline
\end{tabular}

Tabel 2 digunakan untuk mengkombinasikan $m_{1}$ yang merupakan Nilai Kepercayaan panas dengan $m_{2}$ yang merupakan Nilai Kepercayaan tangis merintih.

$$
\begin{aligned}
& \mathrm{m} 3\{\mathrm{~S}, \mathrm{~B}\}=\frac{0.42+0.18}{1-0}=0.6 \\
& \mathrm{~m} 3\{\mathrm{~S}, \mathrm{M}, \mathrm{KD}, \mathrm{B}\}=\frac{0.28}{1-0}=0.28 \\
& \mathrm{~m} 3\{\Theta\}=\frac{0.12}{1-0}=0.12
\end{aligned}
$$

c. Gejala 3: Tidak Mau Minum

Tidak mau minum merupakan gejala dari Sepsis pada Bayi $\{S\}$ dengan nilai kepercayaan adalah 0.5 .

$$
m_{4}\{S\}=0.5 m_{4}\{\Theta\}=0.5
$$

Tabel 3. Kombinasi 3 Gejala

\begin{tabular}{lll}
\hline & $\mathrm{m}_{4}\{\mathrm{~S}\} 0.5$ & $\mathrm{~m}_{4}\{\Theta\} 0.5$ \\
\hline $\mathrm{m}_{3}\{\mathrm{~S}, \mathrm{~B}\} 0.6$ & $\{S\} 0.3$ & $\{\mathrm{~S}, \mathrm{~B}\} 0.3$ \\
$\mathrm{~m}_{3}\{\mathrm{~S}, \mathrm{M}, \mathrm{KD}, \mathrm{B}\} 0.28$ & $\{S\} 0.14$ & $\{\mathrm{~S}, \mathrm{M}, \mathrm{KD}, \mathrm{B}\} 0.14$ \\
$\mathrm{~m}_{3}\{\Theta\} 0.12$ & $\{\mathrm{~S}\} 0.06$ & $\{\Theta\} 0.06$ \\
\hline
\end{tabular}

Tabel 3 digunakan untuk mengkombinasikan $m_{3}$ yang merupakan Nilai Kepercayaan kombinasi 2 gejala dengan $\mathrm{m}_{4}$ yang merupakan Nilai Kepercayaan tidak mau minum.

$$
\begin{aligned}
& \mathrm{m} 5\{S\}=\frac{0.3+0.14+0.06}{1-0}=0.5 \\
& \mathrm{~m} 5\{\mathrm{~S}, \mathrm{~B}\}=\frac{0.3}{1-0}=0.3 \\
& \mathrm{~m} 5\{\mathrm{~S}, \mathrm{M}, \mathrm{KD}, \mathrm{B}\}=\frac{0.14}{1-0}=0.14 \\
& \mathrm{~m} 5\{\Theta\}=\frac{0.06}{1-0}=0.06
\end{aligned}
$$

d. Gejala 4: Sesak

Sesak merupakan gejala dari Sepsis pada Bayi $\{S\}$, Bronkitis $\{B\}$, dan Asma $\{A\}$ dengan nilai kepercayaan adalah 0.55 . $\mathrm{m}_{6}\{\mathrm{~S}, \mathrm{~B}, \mathrm{~A}\}=0.55 \mathrm{~m}_{6}\{\Theta\}=0.45$

Tabel 4. Kombinasi 4 Gejala

\begin{tabular}{lll}
\hline & $m_{6}\{S, B, A\} 0.55$ & $m_{5}\{\Theta\} 0.45$ \\
\hline$m_{5}\{S\} 0.5$ & $\{S\} 0.275$ & $\{S\} 0.225$ \\
$m_{5}\{S, B\} 0.3$ & $\{S, B\} 0.165$ & $\{S, B\} 0.135$ \\
$m_{5}\{S, M, K D, B\} 0.14$ & $\{S, B\} 0.077$ & $\{S, M, K D, B\} 0.063$ \\
$m_{5}\{\Theta\} 0.06$ & $\{S, B, A\} 0.033$ & $\{\Theta\} 0.027$ \\
\hline
\end{tabular}

Tabel 4 digunakan untuk mengkombinasikan $m_{5}$ yang merupakan Nilai Kepercayaan kombinasi 3 gejala dengan $m_{6}$ yang merupakan Nilai Kepercayaan gejala sesak. 


$$
\begin{aligned}
& \mathrm{m} 7\{S\}=\frac{0.275+0.225}{1-0}=0.5 \\
& \mathrm{~m} 7\{\mathrm{~S}, \mathrm{~B}\}=\frac{0.165+0.077+0.135}{1-0}=0.377 \\
& \mathrm{~m} 7\{\mathrm{~S}, \mathrm{~B}, \mathrm{~A}\}=\frac{0.033}{1-0}=0.033 \\
& \mathrm{~m} 7\{\mathrm{~S}, \mathrm{M}, \mathrm{KD}, \mathrm{B}\}=\frac{0.063}{1-0}=0.063 \\
& \mathrm{~m} 7\{\Theta\}=\frac{0.027}{1-0}=0.027
\end{aligned}
$$

e. Gejala 5: Kejang

Kejang merupakan gejala dari Sepsis pada Bayi $\{S\}$, Meningitis $\{M\}$, dan Kejang Demam $\{K D\}$ dengan nilai kepercayaan adalah 0.45 .

$\mathrm{m}_{8}\{\mathrm{~S}, \mathrm{M}, \mathrm{KD}\}=0.45$

$m_{8}\{\Theta\}=0.55$

Tabel 5. Kombinasi 5 Gejala

\begin{tabular}{lll}
\hline & $m_{8}\{S, M, K D\} 0.45$ & $m_{8}\{\Theta\} 0.55$ \\
\hline$m_{7}\{S\} 0.5$ & $\{S\} 0.225$ & $\{S\} 0.275$ \\
$m_{7}\{S, B\} 0.377$ & $\{S\} 0.16965$ & $\{S, B\} 0.20735$ \\
$m_{7}\{S, B, A\} 0.033$ & $\{S\} 0.01485$ & $\{S, B, A\} 0.01815$ \\
$m_{7}\{S, M, K D, B\} 0.063$ & $\{S, M, K D\} 0.02835$ & $\{S, M, K D, B\} 0.03465$ \\
$m_{7}\{\Theta\} 0.027$ & $\{S, M, K D\} 0.01215$ & $\{\Theta\} 0.01485$ \\
\hline
\end{tabular}

Tabel 5 digunakan untuk mengkombinasikan $m_{7}$ yang merupakan Nilai Kepercayaan kombinasi 4 gejala dengan $m_{8}$ yang merupakan Nilai Kepercayaan gejala kejang.

$$
\begin{aligned}
& \mathrm{m}_{9}\{S\}=\frac{0.225+0.16965+0.01485+0.275}{1-0}=0.6845 \\
& \mathrm{~m}_{9}\{\mathrm{~S}, \mathrm{M}, \mathrm{KD}\}=\frac{0.02835+0.01215}{1-0}=0.0405 \\
& \mathrm{~m}_{9}\{\mathrm{~S}, \mathrm{~B}\}=\frac{0.20735}{1-0}=0.20735 \\
& \mathrm{~m}_{9}\{\mathrm{~S}, \mathrm{~B}, \mathrm{~A}\}=\frac{0.01815}{1-0}=0.01815 \\
& \mathrm{~m}_{9}\{\mathrm{~S}, \mathrm{M}, \mathrm{KD}, \mathrm{B}\}=\frac{0.03465}{1-0}=0.03465 \\
& \mathrm{~m}_{9}\{\Theta\}=\frac{0.01485}{1-0}=0.01485
\end{aligned}
$$

f. Gejala 6: Batuk

Batuk merupakan gejala Asma $\{\mathrm{DT}\}$ dengan nilai kepercayaan adalah 0.4.

$\mathrm{m}_{10}\{\mathrm{~A}\}=0.4$

$\mathrm{m}_{10}\{\Theta\}=0.6$

Tabel 6. Kombinasi 6 Gejala

\begin{tabular}{lll}
\hline & $m_{10}\{A\} 0.4$ & $m_{10}\{\Theta\} 0.6$ \\
\hline$m_{9}\{S\} 0.6845$ & $\varnothing 0.2738$ & $\{S\} 0.4107$ \\
$m_{9}\{S, M, K D\} 0.0405$ & $\varnothing 0.0162$ & $\{S, M, K D\} 0.0243$ \\
$m_{9}\{S, B\} 0.20735$ & $\varnothing 0.08294$ & $\{S, B\} 0.12441$ \\
$m_{9}\{S, B, A\} 0.01815$ & $\{A\} 0.00726$ & $\{S, B, A\} 0.01089$ \\
$m_{9}\{S, M, K D, B\} 0.3465$ & $\varnothing 0.01386$ & $\{S, M, K D, B\} 0.02079$ \\
$m_{9}\{\Theta\} 0.01485$ & $\{A\} 0.00594$ & $\{\Theta\} 0.00891$ \\
\hline
\end{tabular}

Tabel 6 digunakan untuk mengkombinasikan $\mathrm{m}_{7}$ yang merupakan Nilai Kepercayaan kombinasi 5 gejala dengan $m_{10}$ yang merupakan Nilai Kepercayaan gejala batuk. Hasil akhir dari perhitungan Dempster-Shafer adalah $\mathrm{m}_{11}$. 


$\mathrm{m}_{11}\{\mathrm{~A}\}=\frac{0.00726+0.00594}{1-(0.2738+0.0162+0.08294+0.01386)}=0.02153$
$\mathrm{~m}_{11}\{\mathrm{~S}\}=\frac{0.4107}{1-(0.2738+0.0162+0.08294+0.01386)}=0.66977$
$\mathrm{~m}_{11}\{\mathrm{~S}, \mathrm{M}, \mathrm{KD}\}=\frac{0,0243}{1-(0.2738+0.0162+0.08294+0.01386)}=0.03963$
$\mathrm{~m}_{11}\{\mathrm{~S}, \mathrm{~B}\}=\frac{0.01089}{1-(0.2738+0.0162+0.08294+0.01386)}=0.01776$
$\mathrm{~m}_{11}\{\mathrm{~S}, \mathrm{~B}, \mathrm{~A}\}=\frac{0.12441}{1-(0.2738+0.0162+0.08294+0.01386)}=0.289$
$\mathrm{~m}_{11}\{\mathrm{~S}, \mathrm{M}, \mathrm{KD}, \mathrm{B}\}=\frac{0.02079}{1-(0.2738+0.0162+0.08294+0.01386)}=0.0339$
$\mathrm{~m}_{11}\{\Theta\}=\frac{0.00891}{1-(0.2738+0.0162+0.08294+0.01386)}=0.01453$

Perhitungan Dempster-Shafer diaplikasikan menggunakan Bahasa Pemrograman PHP dan HTML. Nilai Dempster-Shafer dari 5 kondisi yang dibuat dapat dilihat pada Gambar 2, Gambar 3, Gambar 4, Gambar 5, dan Gambar 6.

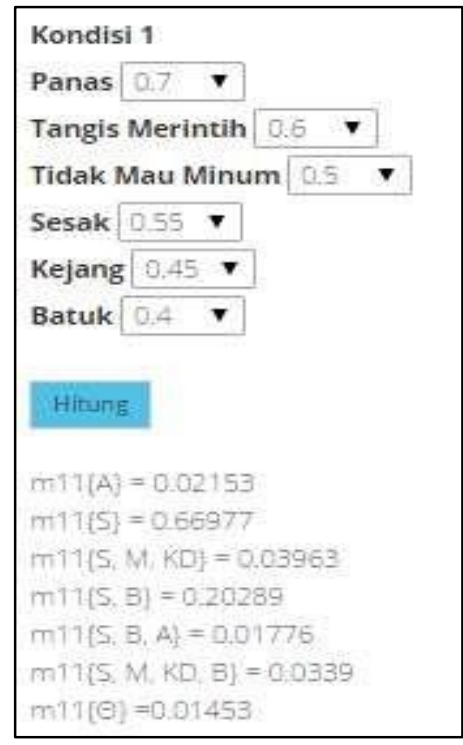

Gambar 2. Hasil Kondisi 1

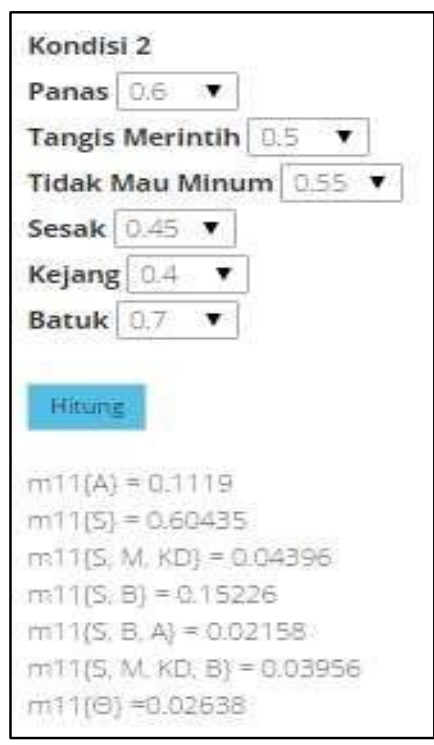

Gambar 3. Hasil Kondisi 2

Gambar 2 merupakan hasil Kondisi 1, dimana Nilai Dempster-Shafer tertinggi adalah Sepsis pada Bayi yaitu 0.66977, sedangkan Gambar 3 merupakan hasik Kondisi 2. Nilai Dempster-Shafer tertinggi pada Kondisi 2 adalah Sepsis pada Bayi yaitu 0.60435.

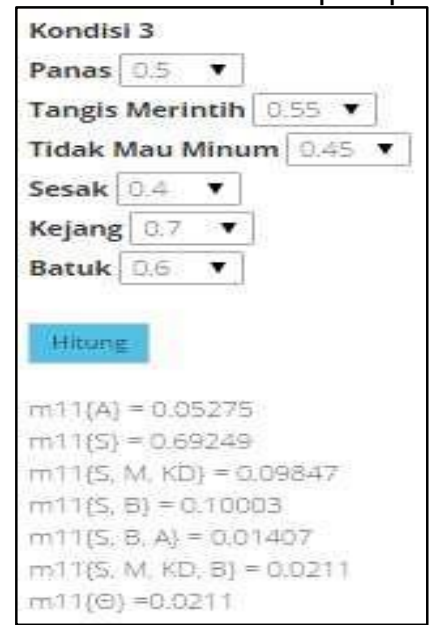

Gambar 4. Hasil Kondisi 3

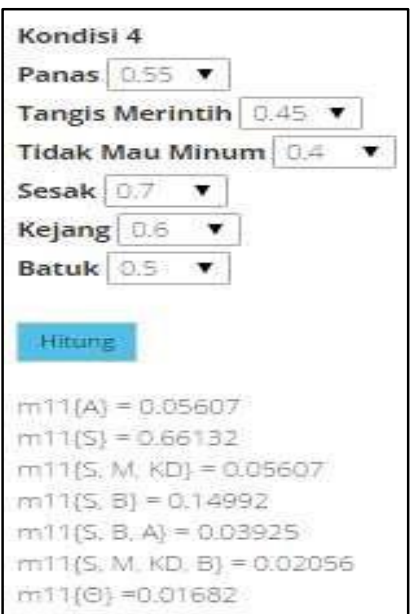

Gambar 5. Hasil Kondisi 4 
Gambar 4 merupakan hasil Kondisi 3 yang Nilai Dempster-Shafer tertinggi adalah Sepsis pada Bayi yaitu 0. 69249, sedangkan Gambar 5 merupakan hasik Kondisi 2, dimana Nilai DempsterShafer tertinggi pada Kondisi 4 adalah Sepsis pada Bayi yaitu 0. 66132.

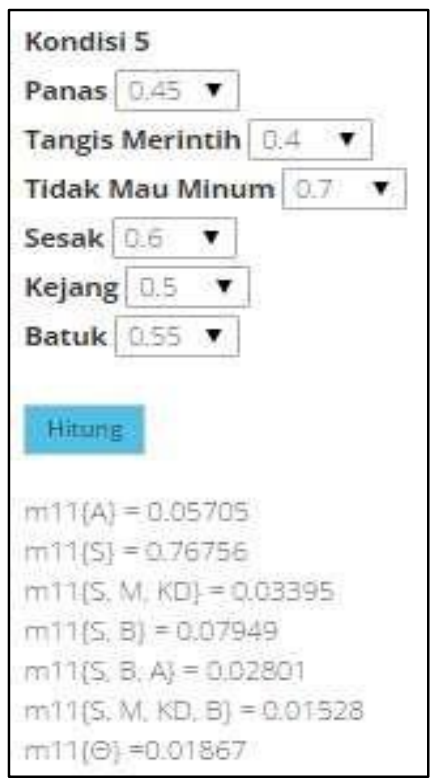

Gambar 6. Hasil Kondisi 5

Gambar 6 merupakan hasil Kondisi 5 yang Nilai Dempster-Shafer tertinggi adalah Sepsis pada Bayi yaitu 0.76756 .

\subsection{Analisa Hasil}

Gambar 7 menunjukkan hasil perhitungan Dempster-Shafer dari 5 kondisi yang berbeda. Hasil perhitungan tertinggi pada setiap kondisi adalah Penyakit Sepsis pada Bayi.

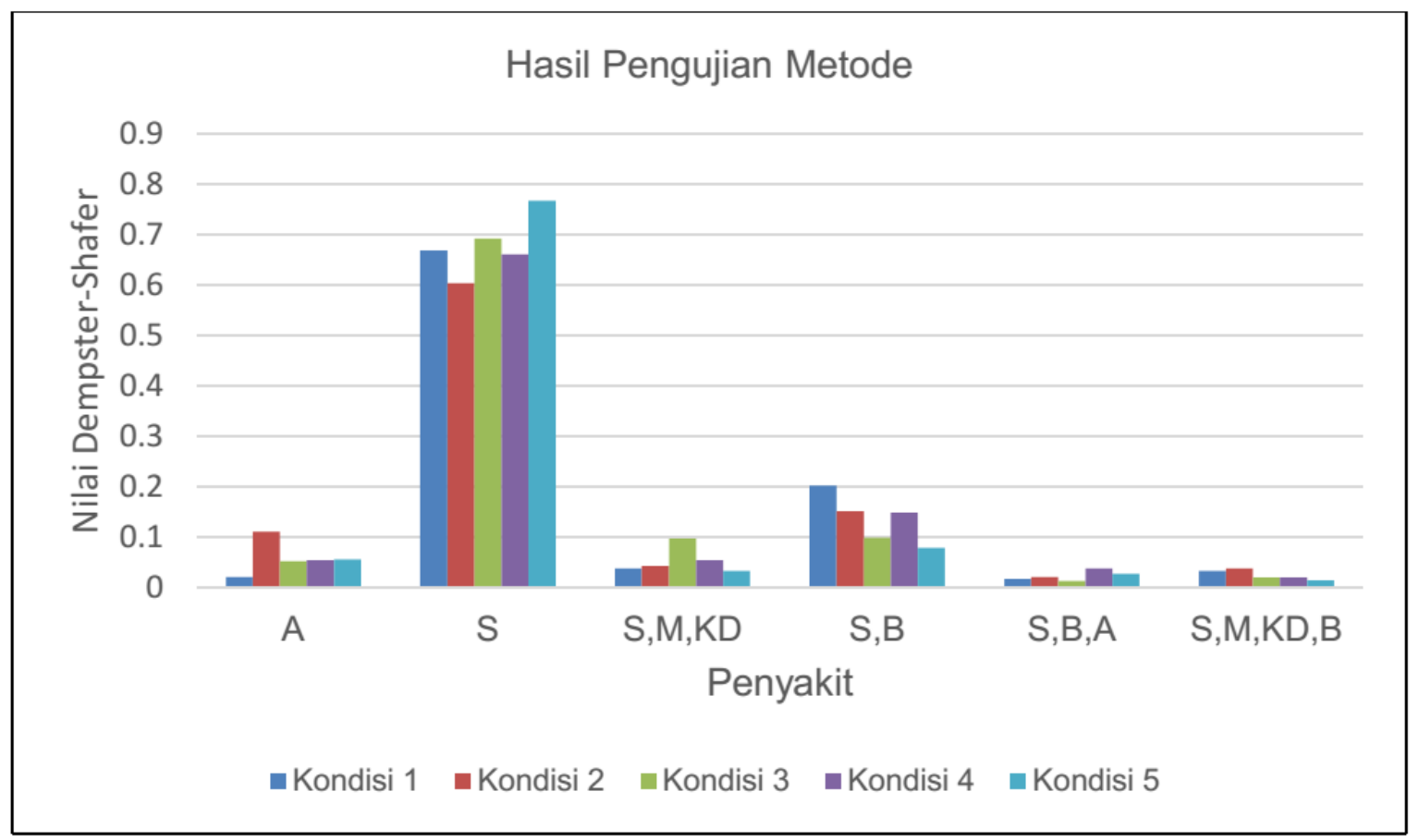

Gambar 7. Nilai Dempster-Shafer dari 5 Kondisi 
Gambar 7. memperlihatkan Nilai Dempster-Shafer dari 5 Kondisi yang diujikan. Nilai DempsterShafer tertinggi pada setiap kondisi adalah Penyakit Sepsis pada Bayi. Nilai Dempster-Shafer untuk Sepsis pada Bayi Kondisi 1 adalah 0.66977, Kondisi 2 adalah 0.60435, Kondisi 3 adalah 0.69249, Kondisi 4 adalah 0.66132, dan Kondisi 5 adalah 0.76756. Nilai Dempster-Shafer tertinggi Penyakit Sepsis pada Bayi terdapat pada Kondisi 5. Gejala pada Kondisi 5 yang memiliki Nilai Kepercayaan tertinggi adalah Tidak Mau Minum yang merupakan gejala dari penyakit Sepsis pada Bayi saja.

\section{Kesimpulan}

Penelitian Deteksi Sepsis pada Bayi Menggunakan Metode Dempster-Shafer menunjukkan bagaimana Metode Dempster-Shafer dapat dimanfaatkan untuk mendeteksi Penyakit Sepsis pada Bayi dengan menelusuri gejala penyakit satu demi satu. Uji coba Metode Dempster-Shafer dapat dilakukan dengan menggunakan Bahasa Pemrograman PHP dan HTML. Metode Dempster-Safer dapat digunakan untuk mendeteksi Penyakit Sepsis pada Bayi pada 5 kondisi yang yang berbeda. Nilai Dempster-Shafer untuk Sepsis pada Bayi yaitu Kondisi 1 adalah 0.66977 , Kondisi 2 adalah 0.60435, Kondisi 3 adalah 0.69249, Kondisi 4 adalah 0.66132, dan Kondisi 5 adalah 0.76756. Nilai Dempster-Shafer tertinggi Penyakit Sepsis pada Bayi terdapat pada Kondisi 5 yaitu 0.76756. Besarnya Nilai Dempster-Shafer ini dipengaruhi oleh Nilai Kepercayaan dan keterkaitan antara gejala suatu penyakit dengan penyakit lainnya.

\section{Daftar Pustaka}

[1] M. Rikki Ardhiareza Arifin, "Hubungan Antara Hiperglikemia dan Mortalitas pada Anak dengan Sepsis di Ruang Rawat Inap Intensif RSUD Dr. Moewardi Surakarta," Jurnal Kedokteran Indonesia, vol. 2, no. 1, pp. 34-38, 2011.

[2] M. Dahria, R. Silalahi, and M. Ramadhan, "Sistem Pakar Metode Damster Shafer Untuk Menentukan Jenis Gangguan Perkembangan Pada Anak," Jurnal IImu Sains dan IImu Komputer., vol. 12, no. 1, pp. 1-10, 2013.

[3] R. S. Hotchkiss et al., "Apoptotic cell death in patients with sepsis, shock, and multiple organ dysfunction," Crit Care Med, 1999.

[4] Kamus Kesehatan.

[5] E. G. Wahyuni and W. Prijodiprojo, "Prototype Sistem Pakar untuk Mendeteksi Tingkat Resiko Penyakit Jantung Koroner dengan Metode DempsterShafer (Studi Kasus: RS. PKU Muhammadiyah Yogyakarta)," IJCCS, vol. 7, no. 2, pp. 133-144, 2013.

[6] E. Setyarini, D. Putra, and A. Purnawan, "The Analysis of Comparison of Expert System of Diagnosing Dog Disease by Certainty Factor Method and Dempster-Shafer Method," International Journal of Computer Science, vol. 10, no. 1, pp. 576-584, 2013. 